\title{
Adverse effect of Maternal Anemia on Fetal Doppler Indices and estimated fetal weight during the Last trimester of pregnancy in rural and suburban area Abdel samie Abdel monaiem Abdelsamie, Al Mandouh Hussein Bosilah, Rana Ahmed Mohammed Farouk
}

\author{
Department of Obstetrics and Gynecology, Faculty of Medicine, Fayoum University
}

\begin{abstract}
Background: Anemia is an important global health problem affecting nearly 529 million women of reproductive age, including 38\% of all pregnant women. Anemia during pregnancy is a key contributor to maternal mortality and poor birth outcomes in both low- and high- income countries. Reducing maternal anemia is widely recognized as central to the health of women and children. Current WHO global targets call for a $50 \%$ reduction of anemia in women of reproductive age by 2025. Maternal anemia is a hypoxic condition that could be responsible for the redistribution of fetal blood flow, however, no evidence of placental insufficiency has been documented currently. In the presence of fetal hypoxemia, vasodilatation of the fetal middle cerebral artery occurs resulting in the so-called "brain sparing effect" to preserve cerebral oxygenation this plays a major role in fetal adaptations to oxygen deprivation (compensatory flow or adaptation changes).
\end{abstract}

Objective: The aim of this study was to evaluate the effect of maternal anemia on fetal Doppler Indices namely umbilical artery and middle cerebral artery and subsequently fetal growth rate.

Patients and Methods: This study was designed as a prospective comparative study was carried out in the Departments of Obstetrics \& Gynecology, Faculty of Medicine, Fayoum University including 200

pregnant women. The pregnant women were divided into three groups: Group A: Patients with mild anemia ( $\mathrm{Hb}$ concentration: $9.0-10.9 \mathrm{~g} / \mathrm{dl}$ ). Group B: Patients with moderate anemia ( $\mathrm{Hb}$ concentration: 7.0- 8.9g/dl). Group C: Patients with severe anemia (Hb concentration: $>7.0 \mathrm{~g} / \mathrm{dl}$ ). A "Mild" is a misnomer: iron deficiency is already advanced by the time anemia is detected. The duration of the study ranged from 6 to 12 months. Patients aged 20-35 years with singleton living fetus of >_32 weeks gestation at time of first visit with no history of chronic illness or medical disorder other than iron deficiency anemia such as chronic hypertension, D.M. or chronic blood loss e.g.; peptic ulcer and no history of recurrent perinatal deaths, recent blood transfusion or other vitamin deficiency anemia

Results:. Our results reported that there was no significant difference between the studied groups regarding age and BMI.As regard fetal Doppler cerebral artery Indices of the three studied groups, the current study shows that there is a significant difference between the three studied groups regarding middle cerebral artery resistance index, middle cerebral artery pulsatility index and middle cerebral artery systolic/diastolic ratio. In the study in our hands, there is a significant difference between the three studied groups regarding umbilical artery resistance index, umbilical artery pulsatility index, umbilical artery systolic/diastolic ratio and middle cerebral/ umbilical artery resistance index. The present study shows that there is a significant difference between the three studied groups regarding biparietal diameter, abdominal circumference and femur length. There is a significant difference between the three studied groups regarding amniotic fluid index at 10 days later and at delivery. our results reported that as for the AFI, no significant effect was noticed in the 3 groups. In the study in our hands, there is a significant difference between the three studied groups regarding middle cerebral artery resistance index at 10 days later and at delivery, umbilical artery resistance index at 10 days later, and middle cerebral/ umbilical artery resistance index at 10 days later and at delivery. There is a significant difference between the three studied groups regarding Apgar at 5 min and birth weight.

Conclusion: There was a significant effect of maternal anemia on fetal Doppler indices in bot umbilical artery and middle cerebral artery in the last trimester of pregnancy and this effect is directly proportionate to the severity of anemia.

Keywords: Hemoglobin concentration, middle cerebral artery resistance index, 
umbilical artery resistance index, middle cerebral/ umbilical artery resistance index, birth weight.

\section{INTRODUCTION}

\section{Aim of the Study}

This study aims to evaluate the effect of maternal anemia on fetal Doppler Indices namely umbilical artery and middle cerebral artery and subsequently fetal growth rate.

\section{Patients and Methods}

Study Design: This study was designed as a prospective a prospective comparative cross sectional study include200 pregnant women who attended.

Study Site: at The Departments of Obstetrics $\&$ Gynecology. Faculty of Medicine, Fayoum University

Duration of the study: The study was done during the period between July 2019 and January 2019.

Sample Size: Total sample size in the study was calculated to be two hundred patients (200). The pregnant women were divided into three groups: - Group A: Patients with mild anemia ( $\mathrm{Hb}$ concentration: 9.0-10.9g/dl). Group B: Patients with moderate anemia (Hb concentration: 7.0$8.9 \mathrm{~g} / \mathrm{dl}$ ). Group C: Patients with severe anemia ( $\mathrm{Hb}$ concentration: $>7.0 \mathrm{~g} / \mathrm{dl}$ ). A "Mild" is a misnomer: iron deficiency is already advanced by the time anemia is detected. The deficiency has consequences even when no anemia is clinically apparent. The hemoglobin cut-off of $11 \mathrm{~g} / \mathrm{dl}$ for pregnant women was first presented in the 1968 .

\section{With the following criteria for three groups:}

Inclusion criteria: Patients aged 20-35 of nutritional anemia. Folate deficiency is common as a result of dietary deficiency or increased demand as in pregnancy. The prevalence of folate deficiency in pregnant patients varies from 1 to $50 \%$. The prevalence is higher among economically deprived patients. B12 vitamin is mostly found in foods of animal origin and deficiency was not reported as a frequent cause of anemia. Anemia due to zinc, copper, vitamin A or other vitamin and minerals are also considered in the literature (3).
Exclusion criteria: Patients with years with singleton living fetus of $>$ _32 weeks' gestation at time of first visit with no history of chronic illness or medical disorder other than iron deficiency anemia such as chronic hypertension, D.M. or chronic blood loss e.g.; peptic ulcer and no history of recurrent perinatal deaths, recent blood transfusion or other vitamin deficiency anemia pregnancy associated disorders as: Preeclampsia, gestational diabetes or placenta previa (recurrent vaginal bleeding) were excluded from the study. 
ISSN: 2536-9482 (Online) Fayoum University Medical Journal Abdel samie et al., 2021,4(1), 1-10

Data management and Statistical Analysis:

Data collected throughout history, basic clinical examination, laboratory investigations and outcome measures coded, entered and analyzed

using Microsoft Excel software. Data were then imported into Statistical Package for the Social Sciences (SPSS version 20.0) (Statistical Package for the Social Sciences) software for analysis. According to the type of data qualitative represent as number and percentage, quantitative continues group represent by mean $\pm \mathrm{SD}$, the following tests were used to test differences for significance; correlation by Pearson's correlation or Spearman's . P value was set at $<0.05$ for significant results $\&<0.001$ for high significant result. Data were collected and submitted to statistical analysis. The following statistical tests and parameters were used.

\section{RESULTS}

Table 1: Demographic data of the three studied groups

\begin{tabular}{|c|c|c|c|c|c|}
\hline & $\begin{array}{c}\text { Group } \\
\boldsymbol{A} \\
(N=67)\end{array}$ & $\begin{array}{c}\text { Group } \\
\text { B } \\
(N=67)\end{array}$ & $\begin{array}{c}\text { Group } \\
\boldsymbol{C}\end{array}$ & $\boldsymbol{F}$ & $\boldsymbol{P}$ \\
& $(N=66)$ & & \\
\hline Age & & & & & \\
(years $)$ & $29.56 \pm$ & $30.7 \pm$ & $31.1 \pm$ & 1.84 & .161 \\
Mean \pm & 5.31 & 4.91 & 4.12 & & \\
SD & & & & & \\
\hline BMI & & & & & \\
$\left(\right.$ kg/m $\left.{ }^{2}\right)$ & $27.29 \pm$ & $26.12 \pm$ & $26.61 \pm$ & 2.08 & .128 \\
Mean \pm & 2.69 & 3.39 & 3.84 & & \\
SD & & & & & \\
\hline
\end{tabular}

Table 1 shows that There is no significant difference between the three studied groups regarding age and BMI.

Table 2: Specific Laboratory parameters of the three studied groups.

\begin{tabular}{|c|c|c|c|c|c|}
\hline & $\begin{array}{c}\text { Group A } \\
(N=67)\end{array}$ & $\begin{array}{c}\text { Group } \\
\text { B }\end{array}$ & $\begin{array}{c}\text { Group } \\
\text { C }\end{array}$ & $\boldsymbol{F}$ & $\boldsymbol{P}$ \\
& & $(N=66)$ & & \\
\hline
\end{tabular}

\begin{tabular}{|c|c|c|c|c|c|}
\hline $\begin{array}{c}\text { Ferritin } \\
(n g / m L) \\
\text { Mean } \pm \\
S D\end{array}$ & $\begin{array}{l}35.2 \pm \\
7.64\end{array}$ & $\begin{array}{c}28.44 \pm \\
8.55\end{array}$ & $\begin{array}{c}22.71 \pm \\
9.65\end{array}$ & 34.8 & .000 \\
\hline $\begin{array}{c}\boldsymbol{R B S} \\
(\mathrm{m} g / d L) \\
\text { Mean } \pm \\
S D\end{array}$ & $\begin{array}{c}110.75 \pm \\
14.5\end{array}$ & $\begin{array}{l}141.96 \\
\pm 17.65\end{array}$ & $\begin{array}{c}111.8 \pm \\
14.52\end{array}$ & 1.32 & .271 \\
\hline
\end{tabular}

Table 2 shows There is a significant difference between the three studied groups regarding ferritin.

Table 3: Fetal biometry of the three studied groups.

\begin{tabular}{|c|c|c|c|c|c|}
\hline & $\begin{array}{c}\text { Group } \\
\boldsymbol{A} \\
(N=67)\end{array}$ & $\begin{array}{c}\text { Group } \\
\boldsymbol{B} \\
(N=67)\end{array}$ & $\begin{array}{c}\text { Group } \\
\boldsymbol{C} \\
(N=66)\end{array}$ & $\boldsymbol{F}$ & $\boldsymbol{P}$ \\
\hline $\begin{array}{c}\text { Biparietal } \\
\text { diameter } \\
\text { Mean } \pm S D\end{array}$ & $\begin{array}{c}77.15 \\
\pm 3.86\end{array}$ & $\begin{array}{c}75.42 \\
\pm 4.53\end{array}$ & $\begin{array}{c}72.87 \\
\pm 5.18\end{array}$ & $\mathbf{8 . 1 4}$ & $\mathbf{. 0 0 0}$ \\
\hline $\begin{array}{c}\text { Abdominal } \\
\text { circumference } \\
\text { Mean } \pm S D\end{array}$ & $\begin{array}{c}25.25 \\
\pm 3.68\end{array}$ & $\begin{array}{c}24.11 \\
\pm 3.92\end{array}$ & $\begin{array}{c}22.34 \\
\pm 4.22\end{array}$ & $\mathbf{9 . 1 8}$ & $\mathbf{. 0 0 0}$ \\
\hline $\begin{array}{c}\text { Femur length } \\
\text { Mean } \pm S D\end{array}$ & $\begin{array}{c}56.9 \pm \\
3.49\end{array}$ & $\begin{array}{c}55.18 \\
\pm 3.98\end{array}$ & $\begin{array}{c}52.97 \\
\pm 4.17\end{array}$ & $\mathbf{1 1 . 1}$ & $\mathbf{. 0 0 0}$ \\
\hline
\end{tabular}

Table 3 shows There is a significant difference between the three studied groups regarding biparietal diameter, abdominal circumference and femur length.

Table 4: Fetal characteristics of the three studied groups

\begin{tabular}{|c|c|c|c|c|c|}
\hline & $\begin{array}{c}\text { Group } \\
\boldsymbol{A} \\
(N=67)\end{array}$ & $\begin{array}{c}\text { Group } \\
\boldsymbol{B} \\
(N=67)\end{array}$ & $\begin{array}{c}\text { Group } \\
\boldsymbol{C} \\
(N=66)\end{array}$ & $F$ & $P$ \\
\hline $\begin{array}{c}\text { Apgar } \\
\text { at } 5 \text { min } \\
\text { Mean } \pm \\
S D\end{array}$ & $\begin{array}{c}8.62 \pm \\
1.46\end{array}$ & $\begin{array}{c}8.81 \pm \\
1.56\end{array}$ & $\begin{array}{c}7.46 \pm \\
2.55\end{array}$ & 14.2 & .000 \\
\hline $\begin{array}{c}\text { Birth } \\
\text { weight } \\
(k g) \\
\text { Mean } \pm \\
\text { SD }\end{array}$ & $\begin{array}{c}3.33 \pm \\
0.98\end{array}$ & $\begin{array}{c}2.91 \pm \\
1.06\end{array}$ & $\begin{array}{c}2.64 \pm \\
1.21\end{array}$ & 5.81 & .002 \\
\hline
\end{tabular}

Table 4 shows that There is a significant difference between the three studied groups regarding Apgar at 5 min and birth weight. 
Table 5: Fetal Doppler cerebral artery Indices of the three studied groups

\begin{tabular}{|c|c|c|c|c|c|}
\hline & $\begin{array}{c}\text { Group } \\
\boldsymbol{A} \\
(N=67 \\
)\end{array}$ & $\begin{array}{c}\text { Group } \\
\text { B } \\
(N=67 \\
)\end{array}$ & $\begin{array}{c}\text { Group } \\
\text { C } \\
(N=66 \\
)\end{array}$ & $\boldsymbol{F}$ & $\boldsymbol{P}$ \\
\hline $\begin{array}{c}\text { Middle } \\
\text { cerebral } \\
\text { artery } \\
\text { resistance } \\
\text { index } \\
\text { Mean } \pm S D\end{array}$ & $\begin{array}{c}.963 \pm \\
.066\end{array}$ & $\begin{array}{c}.939 \pm \\
.041\end{array}$ & $\begin{array}{c}1.08 \pm \\
.079\end{array}$ & $\begin{array}{c}21 . \\
6\end{array}$ & $\begin{array}{c}.00 \\
0\end{array}$ \\
\hline $\begin{array}{c}\text { Middle } \\
\text { cerebral } \\
\text { artery } \\
\text { pulsatility } \\
\text { index } \\
\text { Mean } \pm S D\end{array}$ & $\begin{array}{c}1.41 \pm \\
.225\end{array}$ & $\begin{array}{c}1.47 \pm \\
.165\end{array}$ & $\begin{array}{c}1.62 \pm \\
.155\end{array}$ & $\begin{array}{c}7.9 \\
1\end{array}$ & $\begin{array}{c}.00 \\
1\end{array}$ \\
\hline $\begin{array}{c}\text { Middle } \\
\text { cerebral } \\
\text { artery } \\
\text { systolic/diasto } \\
\text { lic ratio } \\
\text { Mean } \pm S D\end{array}$ & $\begin{array}{c}3.82 \pm \\
.744\end{array}$ & $\begin{array}{c}3.92 \pm \\
.701\end{array}$ & $\begin{array}{c}3.41 \pm \\
.548\end{array}$ & $\begin{array}{c}3.5 \\
6\end{array}$ & $\begin{array}{c}.03 \\
4\end{array}$ \\
\hline $\begin{array}{c}\text { Middle } \\
\text { cerebral } \\
\text { artery peak } \\
\text { systolic } \\
\text { velocity } \\
\text { Mean } \pm S D\end{array}$ & $\begin{array}{r}40.74 \\
\pm 6.33\end{array}$ & $\begin{array}{r}40.78 \\
\pm 6.53\end{array}$ & $\begin{array}{r}42.43 \\
\pm 7.12\end{array}$ & $\begin{array}{c}.46 \\
0\end{array}$ & $\begin{array}{c}.63 \\
4\end{array}$ \\
\hline
\end{tabular}

Table 5 shows that There is a significant difference between the three studied groups regarding middle cerebral artery resistance index, middle cerebral artery pulsatility index and middle cerebral artery systolic/diastolic ratio.

Table 6: Amniotic fluid index of the three studied groups

\begin{tabular}{|c|c|c|c|c|c|}
\hline & $\begin{array}{c}\text { Group } \\
\boldsymbol{A} \\
(N=67)\end{array}$ & $\begin{array}{c}\text { Group } \\
\boldsymbol{B} \\
(N=67)\end{array}$ & $\begin{array}{c}\text { Group } \\
\boldsymbol{C}\end{array}$ & $\boldsymbol{F}$ & $\boldsymbol{P}$ \\
& $(N=66)$ & & \\
\hline $\begin{array}{c}\text { AFI on } \\
\text { admission } \\
(\mathrm{cm}) \\
\text { Mean } \pm \\
\text { SD }\end{array}$ & $13.44 \pm$ & $13.61 \pm$ & $13.39 \pm$ & 2.74 & .087 \\
$\begin{array}{c}\text { AFI 10 } \\
\text { days later } \\
\text { (cm) }\end{array}$ & $12.12 \pm$ & $12.43 \pm$ & $12.78 \pm$ & $\mathbf{4 . 9 2}$ & $\mathbf{. 0 0 7}$ \\
Mean \pm & 1.23 & 1.31 & 1.09 & & \\
\hline
\end{tabular}

\begin{tabular}{|c|c|c|c|c|c|}
\hline SD & & & & & \\
& & & & & \\
\hline AFI at & & & & & \\
delivery & $10.89 \pm$ & $11.24 \pm$ & $11.95 \pm$ & & \\
$(\mathrm{cm})$ & 1.65 & 2.03 & 2.16 & $\mathbf{5 . 0 5}$ & $\mathbf{. 0 0 5}$ \\
Mean \pm & & & & & \\
SD & & & & & \\
\hline
\end{tabular}

Table 6 shows that There is a significant difference between the three studied groups regarding amniotic fluid index at 10 days later and at delivery.

Table 7: Fetal Doppler Umbilical artery Indices of the three studied groups.

\begin{tabular}{|c|c|c|c|c|c|}
\hline & $\begin{array}{c}\text { Group } \\
\qquad \begin{array}{c}\boldsymbol{A} \\
(N=67)\end{array}\end{array}$ & $\begin{array}{c}\text { Group } \\
\boldsymbol{B} \\
(N=67)\end{array}$ & $\begin{array}{c}\text { Group } \\
\text { C } \\
(N=66)\end{array}$ & $F$ & $P$ \\
\hline $\begin{array}{l}\text { Umbilical artery } \\
\text { resistance index } \\
\text { Mean } \pm S D\end{array}$ & $\begin{array}{c}.872 \pm \\
.067\end{array}$ & $\begin{array}{c}.818 \pm \\
.056\end{array}$ & $\begin{array}{c}.987 \pm \\
.062\end{array}$ & 8.63 & .000 \\
\hline $\begin{array}{c}\text { Umbilical artery } \\
\text { pulsatility index } \\
\text { Mean } \pm S D\end{array}$ & $\begin{array}{c}.729 \pm \\
.081\end{array}$ & $\begin{array}{c}.777 \pm \\
.093\end{array}$ & $\begin{array}{c}1.11 \pm \\
.275\end{array}$ & 13.8 & .000 \\
\hline $\begin{array}{c}\text { Umbilical artery } \\
\text { systolic/diastolic } \\
\text { ratio } \\
\text { Mean } \pm S D\end{array}$ & $\begin{array}{c}2.18 \pm \\
.043\end{array}$ & $\begin{array}{c}2.42 \pm \\
.345\end{array}$ & $\begin{array}{c}2.75 \pm \\
.705\end{array}$ & 8.72 & .000 \\
\hline $\begin{array}{c}\text { Middle cerebral/ } \\
\text { Umbilical artery } \\
\text { resistance index } \\
\text { Mean } \pm S D\end{array}$ & $\begin{array}{c}.876 \pm \\
.093\end{array}$ & $\begin{array}{c}.868 \pm \\
.081\end{array}$ & $\begin{array}{c}.978 \pm \\
.084\end{array}$ & 18.7 & .000 \\
\hline
\end{tabular}

Table 7 shows that There is a significant difference between the three studied groups regarding umbilical artery resistance index, umbilical artery pulsatility index, umbilical artery systolic/diastolic ratio and middle cerebral/ umbilical artery resistance index.

\section{DISCUSSION}

Anemia in general is characterized by a decrease in number of red blood cells or less than the normal quantity of hemoglobin. The condition is determined by the expected normal 
range of hemoglobin in a population, and is defined as existing in an individual whose hemoglobin concentration $(\mathrm{Hb})$ has fallen below a threshold lying at two standard deviations below the median for a healthy population of the same demographic characteristics, including age, sex and pregnancy status (4).

Most of the work of erythropoiesis occurs in the bone marrow. It takes about 25 days. In children younger than 5 years old, the marrow of all the bones of the body is enlisted for

According to United Nation declaration 1997, anemia is a major public health problem that needs total elimination. It is estimated that globally two billion people suffer from anemia or iron deficiency (6).

Maternal anemia is frequently associated with premature delivery, reduced neonatal weight, infant iron deficiency, neonatal death, and low APGAR scores at $1 \mathrm{~min}$. It is also suspected to reduce the oxygen supply to the growing fetus, leading to the redistribution of fetal blood flow (7).

\section{following:}

The main results of the study were as

There is no significant difference between the three studied groups regarding age and BMI.

Our results are in agreement with study of Khalafallah et al., (8) as they reported that there was no significant difference between the studied groups regarding age and BMI.

Furthermore, Sharbaf et al., (9) demonstrated that independent t-test analysis did not show any

significant differences between both groups

regarding maternal age $(\mathrm{p}=0.51)$.

Anemia is an important global health problem affecting nearly 529 million women of reproductive age, including 38\% of all pregnant women. Anemia during pregnancy is a key contributor to maternal mortality and poor birth outcomes in both low- and high- income countries. Reducing maternal anemia is widely recognized as central to the health of women and children. Current WHO global targets call for a $50 \%$ reduction of anemia in women of reproductive age by 2025 (10).

The present study shows that there is a significant difference between the three studied producing red blood cells. As a person ages, red blood cells are eventually produced only in the marrow of the spine, ribs, and pelvis (5).

groups regarding $\mathrm{Hb}, \mathrm{MCV}, \mathrm{MCH}$ and $\mathrm{MCHC}$. There is a significant difference between the three studied groups regarding ferritin.

Our results are supported by study of AbdelMegeed et al., (11) as they reported that in this study the hemoglobin level in anemic patients ranged from 5.0-10.9 $\mathrm{g} / \mathrm{dl}$ while in non-anemic was 11-13.8 $\mathrm{g} / \mathrm{dl}$, there was a significant decrease in hemoglobin level in anemic more than non-anemic, these result obeying the inclusion and exclusion criteria.

Furthermore, Kumar et al., (12) found that there is a significant difference between the three studied groups regarding $\mathrm{Hb}, \mathrm{MCV}, \mathrm{MCH}$. Prevalence of anemia in pregnancy is quite high. Their figures showed more than half of the mothers were anemic to start with. Similar figures are quoted in other studies as well. The trend in $\mathrm{Hb}$ level is quite interesting. The mid-trimester drops seen in nonanemic mothers was not seen in anemic mothers. This indicates that mid-trimester drop in $\mathrm{Hb}$ is a very essential physiological arrangement. However, in anemic mothers, as the mean $\mathrm{Hb}$ in the mid-trimester was below that in nonanemic mothers, no drop phenomenon was seen (13).

Furthermore, Lasheen et al., (14) revealed that there was a statistically significant difference among Hb levels on admission among the three studied groups.

The middle cerebral artery (MCA) may also predict fetal outcomes from alterations in cerebral blood flow and its direction. It was confirmed that during the prenatal period, the resistance in the cerebral artery of the fetus is high. However, this parameter can change in threatening conditions, such as placental 
ISSN: 2536-9482 (Online) Fayoum University Medical Journal Abdel samie et al., 2021,4(1), 1-10

insufficiency and hypoxemia, due to stimulation of chemoreceptors and alteration in vasodilator or vasoconstrictor agents. MCA Doppler measurement has been advocated as an efficient modality for detection of fetal hypoxia, which leads to perinatal adverse outcome and fetal compromise (15).

As regard fetal Doppler cerebral artery Indices of the three studied groups, the current study shows that there is a significant difference between the three studied groups regarding middle cerebral artery resistance index, middle cerebral artery pulsatility index and middle cerebral artery systolic/diastolic ratio.

Our results are in line with study of

There was statistically significant relation between the different studied groups regarding Middle cerebral artery resistance index $(\mathrm{P}<0.05)$.

Ali et al., (16) stated that fetal Doppler examination at admission found that severe maternal anemia induced significant hemodynamic changes at the cerebral level. The mean middle cerebral artery resistance index was significantly lower in the anemia group than in the control group. This could be due to hypoxia-induced cerebral vasodilatation affecting the fetus during severe anemia.

Furthermore, Sharbaf et al., (9) demonstrated that with regard to Doppler examination, MCA PI between the studied groups was significantly different.

Some studies have demonstrated that diagnosis and management of FGR rely on umbilical artery Doppler (UAD) and others have shown the benefits of uterine artery Doppler assessment in the first-trimester development of FGR. The value of combining pulsatility indices (PI) of both the umbilical artery (UA) and uterine artery for improving prediction of FGR has also been demonstrated

\begin{abstract}
Abdel-Megeed et al., (11) as they showed comparison between the different studied groups regarding Middle cerebral artery resistance index, pulsatility index, systolic/diastolic ratio and peak systolic velocity. Middle cerebral artery resistance index in control group ranged from 0.792- 0.923 with mean value $0.821 \pm 0.035$, in mild anemia group ranged from $0.78-0.98$ with mean value $7.34 \pm 0.06$, in moderate anemia group ranged from 0.79-0.91 with mean value $0.81 \pm 0.06$, in severe anemia group ranged from $0.56-0.80$ with mean value $0.70 \pm 0.08$.
\end{abstract}


In the study in our hands, there is a significant difference between the three studied groups regarding umbilical artery resistance index, umbilical artery pulsatility index, umbilical artery systolic/diastolic ratio and middle cerebral/ umbilical artery resistance index.

Our results are supported by study of Abdel-Megeed et al., (11) as they reported that the umbilical artery resistance index in control group ranged from $0.50-0.68$, in mild anemia group ranged from 0.54-0.71, in moderate anemia group ranged from $0.59-0.74$, in severe anemia group ranged from $0.60-0.77$. There was statistically significant relation between the different studied groups regarding Umbilical artery resistance index $(\mathrm{P}<0.05)$.

Umbilical artery pulsatility index in control group ranged from $0.77-0.85$, in mild anemia group ranged from $0.60-0.88$, in moderate anemia group ranged from $0.67-0.90$, in severe anemia group ranged from $0.77-1.80$. There was statistically significant relation between the different studied groups regarding Umbilical artery pulsatility index $(\mathrm{P}<0.05)$. Umbilical artery systolic/diastolic ratio in control group ranged from 2.09-2.2, in mild anemia group ranged from 2.13-2.23 with mean value, in moderate anemia group ranged from 2.10-3.40, in severe anemia group ranged from 2.15-4.30. There was statistically significant relation between the different studied groups regarding Umbilical artery systolic/diastolic ratio $(\mathrm{P}<0.05)$.

In Ali et al. (16) study, the middle cerebral/umbilical artery resistance ratio was significantly lower at admission in the anemia group; suggesting that the fetus had adapted to anemic conditions by redistributing blood flow towards brain.

The middle cerebral/umbilical artery resistance ratio in the anemia group increased significantly between admission and 4weeks, and between admission and 6weeks. Severe maternal anemia results in the fetus experiencing a hypoxic state and this triggers a marked fetal cerebral vasodilatation to maintain oxygenation of brain tissue, which was evident in the present study by the observed decrease in the middle cerebral artery resistance index. Long-standing cerebral vasodilatation can result in a fetus experiencing cerebral edema and brain damage.

In moiety \& Ahmed (21) study, as for the CIU ratio, in groups $\mathrm{B}$ and $\mathrm{C}$ [moderate and severe anemia], the $\mathrm{C} / \mathrm{U}$ values were below the normal range $(<1.1)$, which confirms that the fetus had to adapt by increasing its blood flow redistribution towards the brain. Such adaptation was confirmed by the increase of the $\mathrm{C} / \mathrm{U}$ ratio after maternal red blood cell transfusion and parenteral iron supplementation. The increase in cerebral resistance after the transfusion without significant change in umbilical or uterine resistance confirms that maternal anemia does not create placental dysfunction and that the situation can be restored quickly by two units of red blood transfusion to the patient or intravenous iron.

In Group (A) [mild anemia], the $\mathrm{C} / \mathrm{U}$ values were within the normal range, which means that the blood flow distribution between the brain and placenta was normal, despite the maternal hemoglobin content being significantly lower compared to normal

The timing of the measurement of maternal anemia is also variable across studies. This is problematic for meta- analyses, as existing literature suggests a differential impact of maternal $\mathrm{Hb}$ concentration depending on the timing during pregnancy.

For low $\mathrm{Hb}$ concentration, the link with adverse birth outcomes is more evident when $\mathrm{Hb}$ concentration is measured in early pregnancy. As summarized in a recent review, several studies have observed a U- shaped curve for the risk of adverse birth outcomes with maternal $\mathrm{Hb}$, that is, there is a higher risk of adverse outcomes among women with both low and high $\mathrm{Hb}$ concentrations. However, the consistency of this relationship varies based on the trimester of $\mathrm{Hb}$ assessment (19). 
The present study shows that there is a significant difference between the three studied groups regarding biparietal diameter, abdominal circumference and femur length. There is a significant difference between the three studied groups regarding amniotic fluid index at 10 days later and at delivery.

Findings of our results are not coincided with study of Lasheen et al., (14) as they reported that as for the AFI, no significant effect was noticed in the 3 groups but a potential benefit might rise which is the prevention of development of oligohydramnios as pregnancy advances especially in group (C) [severe anemia]. This is similar to what have been reported by Milan et al., (20) in 2005 that there was no statistically significant increase in AFI after treatment.

Anemia in pregnant women has been regarded as detrimental to the fetal growth and pregnancy outcome. Low birth weight and preterm delivery have been persistently linked to anemia in pregnancy. The role of anemia in pregnancy and iron on the growing fetus has been studied in the last few decades.

The outcome of these studies is either inconclusive or at the most supportive of the popular notions held so far regarding pregnancy outcome and anemia. Hence, most of the countries have adopted the policy of supplementing pregnant women with iron and folic acid with a view that increasing the $\mathrm{Hb}$ levels has some beneficial effect (17).

In the study in our hands, there is a significant difference between the three studied groups regarding middle cerebral artery resistance index at 10 days later and at delivery, umbilical artery resistance index at 10 days later, and middle cerebral/ umbilical artery resistance index at 10 days later and at delivery. There is a significant difference between the three studied groups regarding Apgar at 5 min and birth weight.

However, Swain et al., (22) have reported an inverse relation between the second trimester $\mathrm{Hb}$ and birth weight. The analysis of qualitative variables in our data has revealed noteworthy clinically relevant results.
The incidence of low birth weight babies in the two groups remained similar with minimal difference and there was no statistical significance in the first two trimesters. The difference was significant only if the mothers were anemic in the third trimester. Many studies conducted by Levy et al., (23) have reported significant association between low birth weight and maternal anemia.

A retrospective study has shown no association between the first trimester anemia and low birth weight (24). Most of these studies have considered the $\mathrm{Hb}$ levels in the third trimester or at delivery for comparison (23). This could well suggest that third trimester $\mathrm{Hb}$ is an important factor in determining birth weight.

It is well known that rapid growth of fetus occurs in the third trimester. Iron and other micronutrient accretion rates are the highest in the same trimester as well. This physiology explains the association of third trimester $\mathrm{Hb}$ and low birth weight. In contrast to the above, association of preterm delivery with maternal anemia is quite striking. Except for the first trimester, anemia in other trimesters has shown significantly increased incidence of preterm delivery. This association appears strongest in the third trimester. There are many studies conducted by Lone et al., (25) showing similar association.

\section{CONCLUSION}

\section{The present study concluded that:}

There was a significant effect of maternal anemia on fetal Doppler indices in both umbilical artery and middle cerebral artery in the last trimester of pregnancy and this effect is directly proportionate to the severity of anemia.

Close monitoring of the fetal umbilical and cerebral circulation by Doppler examination in anemia pregnant females allows the measurement of the amplitude of the fetal vascular response as in severe maternal anemia strongly associated with marked fetal 
hemodynamic adaptation and trigger fetal blood flow redistribution.

\section{REFERENCES}

1. Calis, J. C., Phiri, K. S., Faragher, E. B., Brabin, B. J., Bates, I., Cuevas, L. E., ... \& Hulshof, P. J. (2016). Research Article (New England Journal of Medicine) Severe anemia in Malawian children. Malawi Medical Journal, 28(3), 99-107.

2. Sawyer, S. L., Tian, L., Kähkönen, M., Schwartzentruber, J., Kircher, M., Majewski, J., ... \& Moilanen, J. S. (2015). Biallelic mutations in BRCA1 cause a new Fanconi anemia subtype. Cancer discovery, 5(2), 135-142.

3. Karaoglu L, Pehlivan E, Egri M (2010): The prevalence of nutritional anemia in pregnancy in an east Anatolian province, Turkey. BMC Public Health, 10: 329.

4. McLean E, Cogswell M, Egli I (2009): Worldwide prevalence of anaemia, WHO Vitamin and Mineral Nutrition Information System,1993-2005. Public Health Nutr., 12: 444-54.

5. Kalantar-Zadeh K, Block G, McAllister CJ, Humphreys MH, Kopple JD (2004): The American Journal of Clinical Nutrition, 80(2): 299-307.

6. RCOG guidelines (2014): New S., Wirth M. Anemia, pregnancy, and maternal mortality: The problem with globally standardized hemoglobin cutoffs. B.J.O.G., 122: 166-9, 2015.

7. CHRISTOPHER V. CHARLES: 2012. Iron Deficiency Anemia: A Public Health Problem of Global Proportions, Public Health-Methodology, Environmental and Systems Issues, Prof. Jay Maddock (Ed.), ISBN: 978-953-51-0641-8.

8. Khalafallah, A., Dennis, A., Bates, J., Bates, G., Robertson, I. K., Smith, L., ...
\& Rasko, J. E. J. (2010). A prospective randomized, controlled trial of intravenous versus oral iron for moderate iron deficiency anaemia of pregnancy. Journal of internal medicine, 268(3), 286-295.

9. Sharbaf, F. R., Movahed, F., Pirjani, R., Teimoory, N., Shariat, M., \& Farahani, Z. (2018). Comparison of fetal middle cerebral artery versus umbilical artery color Doppler ultrasound for predicting neonatal outcome in complicated pregnancies with fetal growth restriction. BIOMEDICAL RESEARCH AND THERAPY, 5(5), 2296-2304.

10. WHO . 2014. Global nutrition targets 2025: anaemia policy brief (WHO/NMH/NHD/14.4). Geneva: World Health Organization.

11. Abdel-Megeed, A. M. I., Riad, A. A. M., \& Elsherif, S. M. M. M. (2018). Effect of Maternal Anemia on Fetal Doppler Indices during the Last Trimester of Pregnancy. The Egyptian Journal of Hospital Medicine, 73(2), 6082-6089.

12. Kumar, K. J., Asha, N., Murthy, D. S., Sujatha, M. S., \& Manjunath, V. G. (2013). Maternal anemia in various trimesters and its effect on newborn weight and maturity: an observational study. International journal of preventive medicine, 4(2), 193.

13. Kalaivani K. 2009. Prevalence and consequences of anemia in pregnancy. Indian J Med Res.;130:627-33.

14. Lasheen, Y. S. A. (2011). Effect of maternal iron deficiency anemia on fetal cerebral hemodynamic response by doppler, biophysical profile and APGAR score.

15. Nomura, JI Niigaki, FT Horigome, RPV Francisco, M Zugaib. 2013. Doppler velocimetry of the fetal middle cerebral 
artery and other parameters of fetal wellbeing in neonatal survival during pregnancies with placental insufficiency. Revista da Associação Médica Brasileira.; 59 : 392-399.

16. Ali E, Kumar M, Naqvi SE et al. (2016): Fetal vascular adaptation before and after treatment of severe maternal anemia in pregnancy. International Journal of Gynecology and Obstetrics, 133(3): 284286.

17. Kalaivani K.2009. Prevalence \&amp; consequences of anaemia in pregnancy. Indian J Med Res. 2009 Nov; 130(5):62733.

18. Levytska, $M$ Higgins, $S$ Keating, $N$ Melamed, M Walker, NJ Sebire. 2017. Placental pathology in relation to uterine artery Doppler findings in pregnancies with severe intrauterine growth restriction and abnormal umbilical artery Doppler changes. American journal of perinatology.; 34 : 451-457.

19. Dewey K.G. \& Oaks B.M.. 2017. Ushaped curve for risk associated with maternal hemoglobin, iron status, or iron supplementation. Am. J. Clin. Nutr. 106(Suppl. 6): 1694s-1702s.

20. MILAN MILOSAVLJEVIC M., RADOVICJANOFEVIC V., KUTLESIC R. and VUKOMANOVIC P2005..: Maternal anemia and fetal cerebral hemodynamic response-Doppler assessment. Medison and Biology, (1.12) No. 2 : 93-96,

21. Moiety G and Ahmed Y (2012): Health care professionals, teachers, students and information professionals Arab World rely on Medical journal of Cairo university as a trusted source.The Medical Journal of Cairo University, 80(2): 15-35.

22. Rasmussen S, Oian P. 1993. First- and second-trimester hemoglobin levels.
Relation to birth weight and gestational age. Acta Obstet Gynecol Scand. May; 72(4):246-51.

23. Levy A, Fraser D, Katz M, Mazor M, Sheiner E.2005. Maternal anemia during pregnancy

is an independent risk factor for low birthweight and preterm delivery. Eur $\mathrm{J}$ Obstet Gynecol Reprod Biol. 2005 Oct 1; 122(2):182-6.

24. Phaloprakarn C, Tangjitgamol S.2008. Impact of high maternal hemoglobin at first antenatal visit on pregnancy outcomes: a cohort study. J Perinat Med. 2008; 36(2):115-9.

25. Lone FW, Qureshi RN, Emanuel F.2004. Maternal anaemia and its impact on perinatal outcome. Trop Med Int Health. 2004 Apr; 9(4):486-90 